\title{
In Memory of Lloyd Eastman (1929-93)
}

\section{John Israel}

Lloyd Eastman and I were members of the cohort of American graduate students that entered modern China studies in the 1950s. Our numbers were so small that it was possible to know almost everybody in the field and to grow personally as well as professionally close to one's contemporaries. Since we became friends before we became colleagues, I cannot discuss Lloyd the scholar without recalling Lloyd the man.

Lloyd and I first met at Harvard in the late 1950s, but preoccupation with language study and Ph.D. orals kept most graduate students in their own cocoons. Friendships flourished later in semi-tropical Taipei's Inter-University Program for Field Training in Chinese, located at the "Cornell Center" on Renai Road. There were six of us in the class of 1960-61: Paul Cohen, James Dew, Ramon Myers, Lyman Van Slyke, and the two of us.

Lloyd and I walked into class with the same Chinese surname, "Yi." To distinguish between us, our teachers referred to me as "Yi Youhu" (Mustachioed Yi) and to Lloyd as "Yi Wuhu" (Unmustachioed Yi). The names stuck, and we declared ourselves kinsmen. I called Lloyd Gege - Older Brother - and he called me Didi - Younger Brother. Our nominal fraternity quickly became a reality. Together we hiked and biked all over the island and explored small eateries for lunch. One day we walked into a restaurant with a sign reading "Cantonese Health Foods." The patrons were eating some kind of stew that simmered in aluminium pots on top of Japanese-style braziers, and the steam filled the place with a heady aroma. "What is everybody eating?" we asked. "Xiangrou," replied the waiter. Fearing that foreigners would not catch the euphemism, a customer shouted across the room, "E, ta de yisi jiushi gourou!" - "Yeh, he means dogmeat." I looked at Lloyd, Lloyd looked at me, and we sat down to share a new culinary experience. Bonded by that dogmeat lunch, the brothers $\mathrm{Yi}$ became inseparable.

In the auditorium of the United States Information Agency on Nanhai Road our language school performed a play entitled Huijia Yihou (Homecoming). The plot centred on a Chinese student who had left his village wife and gone off to study in America, whence he returned with a second spouse, an America virago. Because the playwright, Ouyang Yuqian, had stayed on the mainland after 1949 and was therefore anathematized as a cultural pawn of the "Communist bandits," his work could neither be attributed to its author nor performed under its original name. One of our teachers solved the problem by changing the title to $Y u$ yu Xiongzhang (Fish and Bear's Paws) - a reference to Mencius' preference for righteousness ("bear's paws") over life ("fish") if he could not enjoy both together.

I was the returned student. Jim Dew played my Chinese fish. Our school's director, Betsy Mirsky, was my American bear's paws. Lloyd was an old family retainer who, in his simple, rustic way, tried to set me straight with

(C) The China Quarterly, 1994 
lines like, "Young master, how could you have done such a thing?" Lloyd was well cast. Tall, raw-boned, with prognathic teeth, speaking a flat, unaccented Chinese (the same way he spoke English), Lloyd looked and sounded more like a farmer than an intellectual. In fact his academic career had been preceded by a brief stint as a machinist and had been interrupted by a tour in the army.

As a student of John King Fairbank (b. 1907 in Huron, South Dakota) I should have known that Lloyd (b. 1929 in New Rockford, North Dakota) must not be underestimated. But I could scarcely imagine that my bare-chested companion in scaling the peaks of Taiwan would ever reach the summits of academe.

Anyone who didn't take Lloyd seriously was in for a surprise. His first book, Throne and Mandarins: China's Search for a Policy during the Sino-French Controversy, 1880-1885 (1967), was among the most nuanced and sophisticated of the late Qing monographs produced under Fairbank's direction during the 1950s and 1960s. With the publication of The Abortive Revolution: China Under Nationalist Rule, 1927-1937 (1974) and Seeds of Destruction: Nationalist China in War and Revolution, 1937-1949 (1984), Lloyd redirected his attention to the 1927-49 era.

Lloyd moved into a near vacuum of scholarship. During the Kuomintang's two decades in power, study of Chiang Kai-shek's China had been the preserve of social scientists and journalists. After 1949, the Chinese Nationalist were eclipsed by the Communists, academically as well as politically. Lack of serious study did little, however, to inhibit judgments about the Kuomintang's debacle. To mainstream American China specialists, the lessons seemed clear enough: conservative, corrupt, capable of mobilizing neither the revolutionary potential of peasants nor the nationalism of students, the KMT was doomed to failure in its contest with the Communists. This characterization was challenged by pro-Taiwan diehards, who blamed Chiang's defeat on Japanese aggression, Soviet conspiracy and American perfidy, and augmented by Marxists, who wrote off Chiang's government as a tool of landlords, capitalists and imperialists. Until Eastman came along, however, interpretations of the Nationalist era were little more than assertions of opinion. Nobody had taken an impartial look at the record.

Little wonder. Compared to the late Qing, which could be researched through familiar compendia of published documents, the Republican period in general and the 1927-49 era in particular were terra incognita. Materials were scattered in repositories in the United States, Europe, Taiwan, Hong Kong and the still inaccessible mainland. Bibliographic resources were minimal. Key players in the Kuomintang's tragedy could be found on Taiwan and elsewhere, but the handful of scholars who recognized the value of oral history were fighting a losing battle as one politician and general after another took his secrets to the grave.

Lloyd had the vision to realize the urgency of studying Nationalist China and the patience to ferret out and assemble the evidence. He understood the need for synthesis but realized that none would be possible until there was something to synthesize. His two books on Nationalist China were 
meant to begin the process by putting in place major pieces of the puzzle. Each was a collection of mini-monographs on various dimensions of the Kuomintang, spanning a wide range of subjects in political, social and economic history and demonstrating the author's ability to bring to bear comparative and theoretical insights. A look at some of the chapter titles reminds us of Lloyd's virtuosity. In The Abortive Revolution he wrote on "The Blue Shirts and Fascism," "The Fukien Rebellion," "Democracy and Dictatorship," "Nanking and the Economy" and "Social Traits and Political Behavior in Kuomintang China." Seeds of Destruction included treatments of "Regional Politics and the Central Government: Yunnan and Chungking," "Peasants, Taxes, and Nationalist Rule," the Youth Corps, the army, and "Chiang Ching-kuo and the Gold Yuan Reform."

Lloyd's work copiously documented critics' charges of Kuomintang short-sightedness, incompetence and greed, while rejecting simple explanations as to underlying causes. Borrowing Chiang Kai-shek's admission of 1932 - "The Revolution Has Failed" - for the title of the opening chapter of his first volume, Eastman showed that the Nanking government had begun to run out of steam almost as soon as it was established. The myth about a decade of hope cut short by Japanese invasion and Communist rebellion clearly was untenable. In the closing chapter of his second volume - "Who Lost China? Chiang Kai-shek Testifies" - Lloyd again quoted Chiang to discredit the argument that the KMT had anyone but itself to blame for its demise. How could Chiang's followers parrot the formula of Soviet conspiracy and American treachery when their revered leader spurned such easy excuses?

Since he knew that the pieces would never fit together by themselves, Lloyd proposed a new interpretation. The Nationalists' problem, he argued, was not that their power depended upon the support of reactionary social classes but that it had no social base whatsoever, a weakness compounded by personal habits and institutional patterns rooted in Chinese culture. Though Lloyd never actually wrote a full-length history of the 1927-49 era, he began to tie together the threads of the Kuomintang's pre-war and wartime years in chapters three and seven of The Cambridge History of China, volume 13.

Lloyd knew, of course, that definitive treatment of the era would be impossible without an understanding of Chiang Kai-shek, and yet there was no adequate biography of this towering figure. Though Lloyd didn't live to write such a work, in his final years he edited Chiang Kai-shek's Secret Past: The Memoir of His Second Wife, Ch'en Chieh-ju (1993), a document challenged from both sides of the Taiwan Straits yet likely to remain essential reading for anyone who wants to understand Chiang.

Having published seminal works, trained graduate students to follow in his footsteps, and led the way in establishing the journal Republican China, Lloyd became recognized as the doyen of Nationalist China scholars. By that time, his inquisitive intellect had led him into the vast realm of modern Chinese social and economic history. There, he discovered, recent scholarship had explored the parts without defining the whole. Synthesis was needed. The result was Family, Fields, and Ancestors: Constancy and 
Change in China's Social and Economic History, 1550-1949 (1988), a bold foray into a self-taught field. This work met the needs of a diverse readership from neophyte undergraduates to established scholars.

Ever critical of political bias and ideological dogmatism, Lloyd was no stranger to controversy. He expressed himself with wry humour and respected opposing views, but refused to sacrifice integrity on the altar of expediency. At a memorial service in Champaign-Urbana on 30 October 1993, his long-time friend and colleague at the University of Illinois, Peter Schran, recalled how Lloyd had outraged his hosts at a Shanghai banquet when he told an official who pressed him to compare Shanghai with Taipei that Shanghai in 1976 was like Taipei in 1961.

Because Lloyd was both frank and open to dialogue, he generally won the respect and friendship of his critics. At professional conventions, he could be seen bantering with his old schoolmate from Taipei language school days, Ramon Myers, whose positive assessment of the Kuomintang contrasted with Lloyd's negative one. Over the years he carried on a lively dialogue with scholars at the Academia Sinica's Institute of Modern History. As Lloyd's younger brother, I became a junior partner in this enterprise, but I never could equal his disarming, non-confrontational style. The enduring ties between the institute and America's Republican China specialists are a tribute, among other things, to Lloyd's wit and sensitivity.

Lloyd's sense of empathy, his ability to put aside his own problems while engaging himself with those of others, was never more evident than during his final years. While he battled with a brain tumour, I was going through the breakup of a marriage. Every time I phoned to see how he was, Lloyd would dismiss his own crisis with a few self-effacing remarks, redirecting the discussion to my troubles. Soon it was he who was offering solicitude to me - as if his struggle for life was scarcely worth mentioning.

My older brother Lloyd taught by personal example. From him I learned that life and death are not sequential but simultaneous, that the way to face death is to go on living. These lessons were part of Lloyd's legacy - a legacy of friendship, honesty, zest for life and love of learning. I miss him. 